\title{
Epidemiological profile of patients with non-variceal upper gastrointestinal bleeding secondary to peptic disease in a tertiary referral Brazilian hospital
}

\author{
Marcela FORGERINI ${ }^{1}$, Gustavo URBANO ${ }^{2}$, Tales Rubens de NADAl ${ }^{3}$, Maruxa ZAPATA-CACHAFEIRO ${ }^{4}$, \\ Rafael KEMP5 and Patrícia de Carvalho MASTROIANNI ${ }^{6}$
}

Received: 23 September 2020 Accepted: 15 December 2020

\begin{abstract}
Background - Non-variceal upper gastrointestinal bleeding (NVUGIB) secondary to peptic ulcer disease is a medical digestive emergency and could be one of the most serious adverse drug reactions. Objective - To identify the frequency of diagnosis of NVUGIB secondary to peptic ulcer disease. Methods - Prospective and epidemiological study conducted in a tertiary referral Brazilian hospital, from July 2016 to December 2019. Upper gastrointestinal endoscopies (UGE) reports were evaluated daily. The diagnosis of NVUGIB secondary to peptic ulcer disease was defined through endoscopic findings of peptic ulcer and erosive gastric lesions, and clinical symptoms. The frequency of diagnosis of NVUGIB secondary to peptic ulcer disease was estimated through the ratio between the number of patients diagnosed and the number of patients underwent UGE in the same period. Results - A total of 2,779 endoscopic reports (2,503 patients) were evaluated, and 178 patients were eligible. The total frequency of diagnosis of NVUGIB secondary to peptic ulcer disease was 7.1\%. The annual frequency of diagnosis between 2017 and 2019 ranged from 9.3\% to 5.7\%. Most patients were men (72.8\%); self-declared white (71.8\%); older people (56.7\%); and, had no familiar or personal history of gastrointestinal diseases $(60.1 \%) .90 \%$ of the patients had a peptic ulcer and melena $(62.8 \%)$. Patients made chronic use of low-dose aspirin (29.3\%), other antiplatelet agents (21.9\%) and, oral anticoagulants (11.2\%); and non-steroidal anti-inflammatories use in the week a prior to the onset of clinical symptoms (25.8\%). Conclusion - Seven in every 100 patients admitted and underwent UGE in a tertiary hospital were diagnosed with NVUGIB secondary to peptic ulcer disease.
\end{abstract}

Keywords - Gastrointestinal endoscopy; gastrointestinal hemorrhage; epidemiology; hospitalization; patient safety; peptic ulcer.

\section{INTRODUCTION}

Upper gastrointestinal bleeding (UGIB) is considered a medical emergency ${ }^{(1,2)}$ associated with hospitalizations ${ }^{(3)}$ and high morbimortality due to the need for surgical interventions, 30-day hospital readmissions and, in-hospital mortality ${ }^{(4)}$. The mortality ranges from 1.1 to $11 \%$ and even $26 \%$ in inpatients ${ }^{(6)}$.

UGIB has a variceal and non-variceal (NVUGIB) etiology(7), being NVUGIB the etiology with the highest incidence ${ }^{(1)}$ and it is also one of the most serious adverse drug reactions ${ }^{(8)}$. Peptic ulcers and gastroduodenal erosions, which are commonly associated with Helicobacter pylori infection ${ }^{(9)}$ and exposure to certain drug classes (i.e. antiplatelet agent, non-steroidal anti-inflammatories and, oral anticoagulants) $)^{(10-12)}$, are the most common cause of NVUGIB, followed by malignancies, Dieulafoy lesions, angiodysplasia, and Mallory Weiss tear ${ }^{(1)}$.
Most of the studies were conducted in developed countries and reported the epidemiological profile, associate risk factors ${ }^{(13,14)}$ and the frequency of diagnosis and incidence of UGIB including variceal etiology ${ }^{(15,16)}$. However, little is known regarding NVUGIB due complications of peptic ulcer disease and as a possible adverse drug reaction ${ }^{(17,18)}$; and we are not aware of any Brazilian study. In this context, it was intended to identify the frequency of diagnosis of NVUGIB due complications of peptic ulcer disease and to report the epidemiological profile of these patients in a tertiary referral Brazilian hospital.

\section{METHODS}

\section{Study design and ethical aspects}

A prospective observational study was conducted and the report was based on Strengthening the Reporting of Observational

Declared conflict of interest of all authors: none

Disclosure of funding: Conselho Nacional para o Desenvolvimento Científico e Tecnológico - CNPq, (Funding Number: 401060/2014-4), The São Paulo Research Foundation - FAPESP (Funding Number 2017/24193-3 and 2018/07501-9), and Programa de Apoio ao Desenvolvimento Cientifico (PADC) of School of Pharmaceutical Sciences/UNESP, Brazil. This study was financed in part by the Coordenação de Aperfeiçoamento de Pessoal de Nível Superior - Brasil (CAPES) - Finance Code 001.

${ }^{1}$ Universidade Estadual Paulista (UNESP), Faculdade de Ciências Farmacêuticas, Departamento de Fármacos e Medicamentos, Araraquara, SP, Brasil. ${ }^{2}$ Faculdade de Medicina da Universidade de São Paulo, Departamento de Cirurgia, Ribeirão Preto, SP, Brasil. ${ }^{3}$ Faculdade de Medicina da Universidade de São Paulo, Departamento de Saúde Coletiva, Bauru, SP, Brasil. ${ }^{4}$ University of Santiago de Compostela, Department of Preventive Medicine, Santiago de Compostela, Spain. ${ }^{5}$ Faculdade de Medicina da Universidade de São Paulo, Departamento de Cirurgia Digestiva, Ribeirão Preto, SP, Brasil. ${ }^{6}$ Faculdade de Ciências Farmacêuticas da Universidade Estadual Paulista (UNESP), Departamento de Fármacos e Medicamentos, Araraquara, SP, Brasil.

Corresponding author: Patrícia de Carvalho Mastroianni. E-mail: patricia.mastroianni@unesp.br 
Studies in Epidemiology (STROBE) $)^{(19)}$. This study was approved by the Research Ethics Committee of the Clinical Hospital of the Ribeirão Preto Medical School of the University of São Paulo, under protocol n. 1.657.615.

\section{Setting and participants}

This study was conducted at the emergency unity of Clinical Hospital of the Ribeirão Preto Medical School of the University of São Paulo, Brazil. The unity has 300 beds and comprises the Regional Health Directory XIII population, which includes Ribeirão Preto and other 25 municipalities in the region (about 1,471,172 inhabitants).

From July 2016 to December 2019, all upper gastrointestinal endoscopy (UGE) of patients admitted to the Emergency Unity were monitored daily by three researchers independently (Forgerini M, Urbano G and Nadai TR). The UGE reports were evaluated according to the endoscopic findings in addition to the clinical symptoms of the patient. In cases of disagreement regarding the diagnosis of NVUGIB secondary to peptic ulcer disease; the research team discussed the clinical cases and reached a consensus. In order to control the initial discrepancy rates before the consensus, the index of agreement between researchers (kappa) was calculated. The process of daily monitoring and analysis of endoscopic reports and medical records is described in FIGURE 1.
The diagnosis of NVUGIB secondary to peptic disease was defined as endoscopic findings of ulcer, cardiac or pyloric erosions, acute gastric mucosal lesions and, erosive gastritis or duodenitis with or without active or recent bleeding and clinical symptomatology (hematemesis, melena, hematochezia, intense sweating, dizziness, abdominal pain, nausea and vomiting). Stigmata of active or recent bleeding ulcer were classified according to the Forrest classification: Forrest Ia (active spurting bleeding); Ib (active oozing bleeding); IIa (non-bleeding visible vessel); IIb (adherent clot); IIc (spots on base ulcer) and III (clean-base ulcer) ${ }^{(20)}$. Patients who underwent endoscopic hemostasis were identified.

Primary and secondary exclusion criteria were considered. Primary exclusion: (i) patients under 18 years of age; (ii) excludable endoscopic diagnosis (e.g., varices, Mallory-Weiss tear, cirrhosis); (iii) admission not due to NVUGIB secondary to peptic ulcer disease; (iv) pathological antecedents (malignancies and acquired immunodeficiency syndrome); (v) in-hospital NVUGIB; and (vi) probe holders (nasogastric, enteral or subcutaneous). Secondary exclusion: (i) discharge from hospital in the 15 days before to current hospital admission; (ii) endoscopy performed more than 48 hours after hospital admission; (iii) patients with severe health condition and without a familiar member to consent the participation in the study; (iv) patient died before the interview (death); (v) impossibility to perform the interview within 15 days after admission; and, (vi) patient living in a closed institution FIGURE 2.

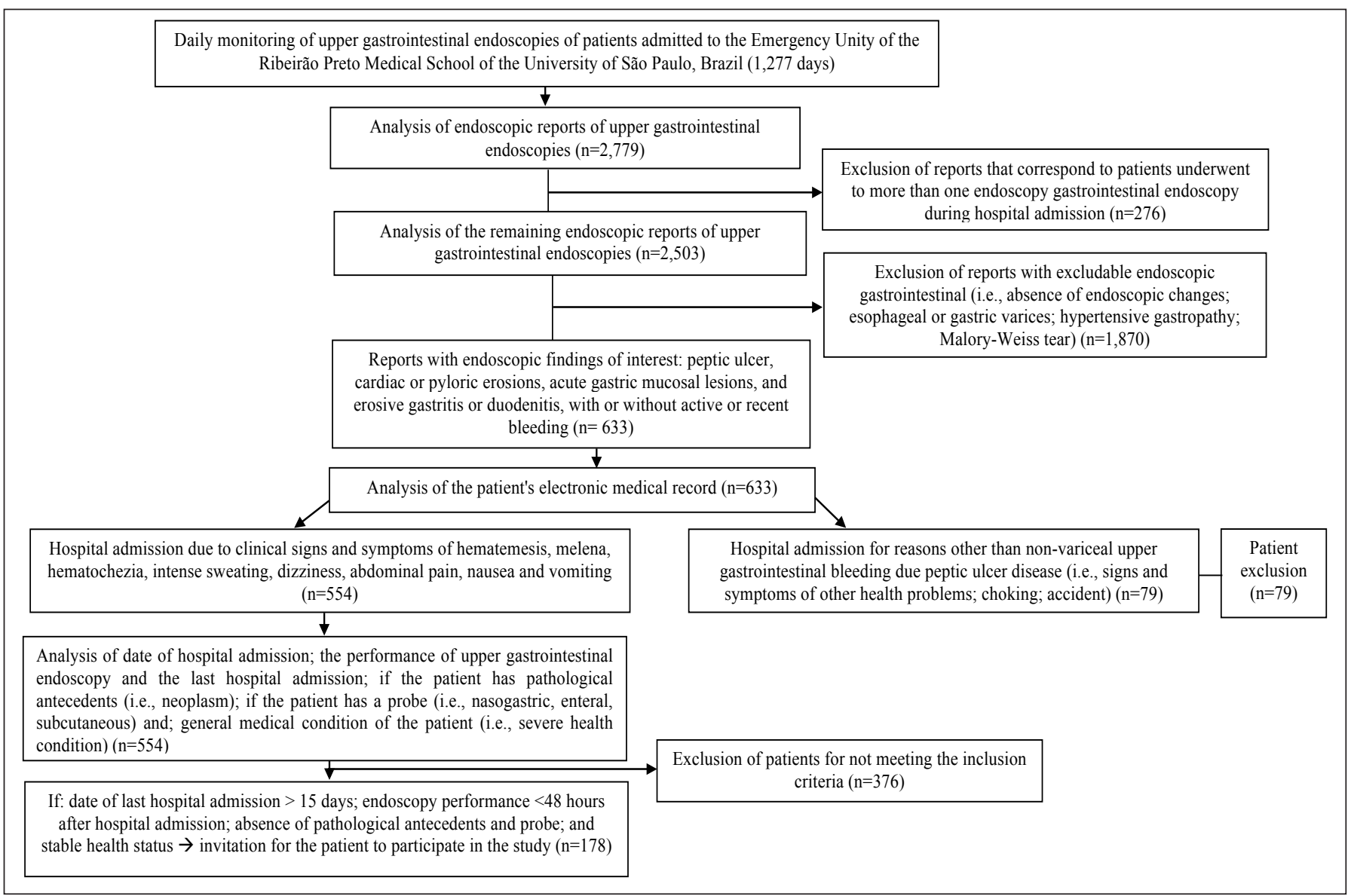

FIGURE 1. Flowchart of the monitoring and analysis process of upper gastrointestinal endoscopies of patients admitted to the Emergency Unity of Clinical Hospital of the Ribeirão Preto Medical School of the University of São Paulo. 


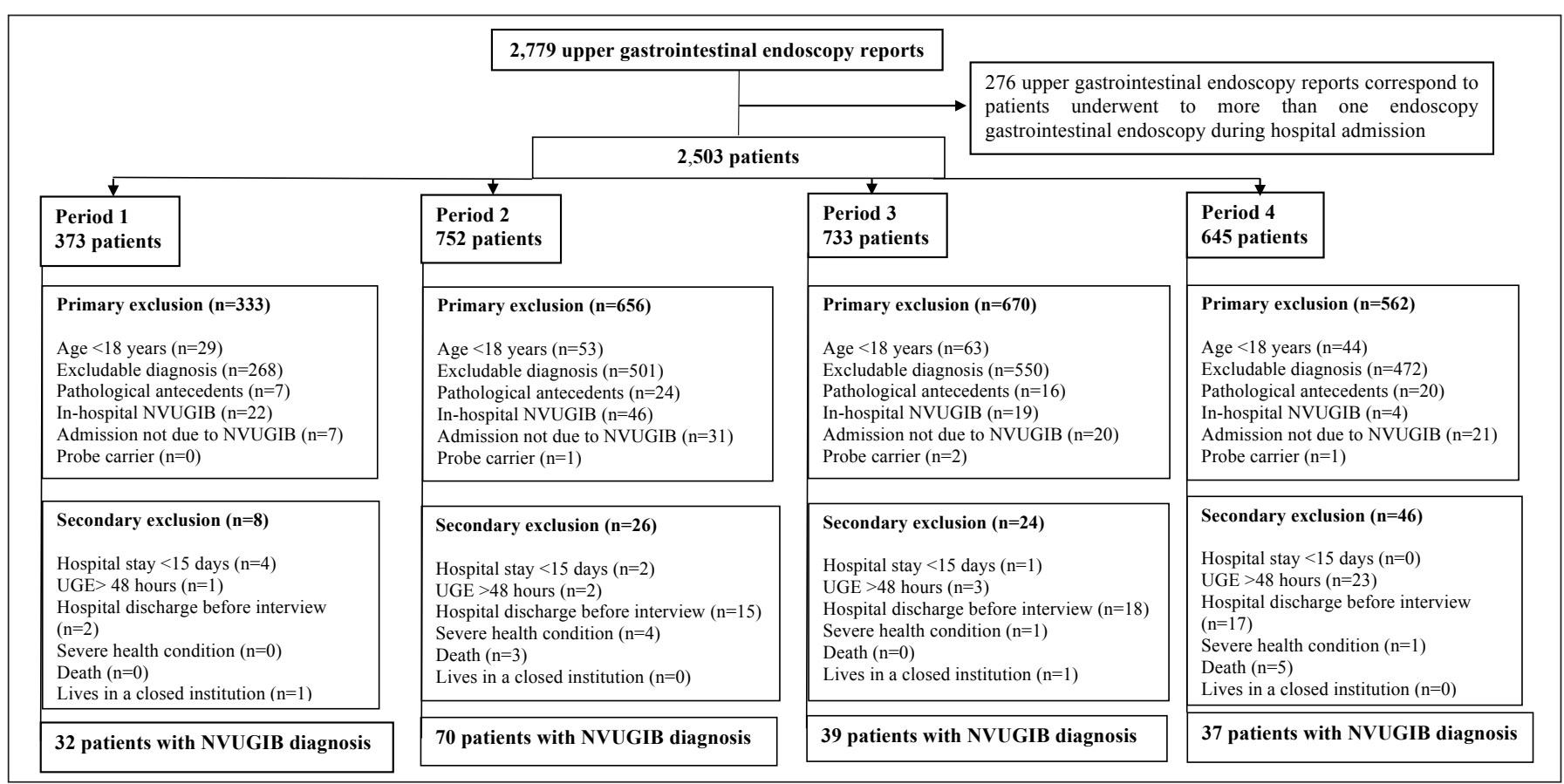

FIGURE 2. Flowchart of evaluation of upper gastrointestinal endoscopy reports, identification of patients diagnosed with non-variceal upper gastrointestinal bleeding secondary to peptic ulcer disease and the respective primary and secondary exclusions, according to the four periods established in this study. NVUGIB: non-variceal upper gastrointestinal bleeding secondary to peptic ulcer disease; UGE: upper gastrointestinal endoscopy.

Four periods of study: (1) July 2016 to December 2016; (2) year 2017; (3) year 2018; and, (4) year 2019.

\section{Variables, data sources and measurement}

NVUGIB secondary to peptic ulcer disease diagnosis was considered the outcome. Demographic and clinical variables were collected through interviews led by two physicians (Urbano G and Nadai TR).

The interviews were conducted through a standardized questionnaire ${ }^{(17)}$ with the patient and/or familiar and, scores from zero to ten were assigned according to the reliability of the information obtained (TABLE 1).

\section{Statistical methods}

The UGE of patients admitted to the Emergency Unity were evaluated for 42 months (July 2016 to December 2019). When the same patient underwent more than one UGE during the hospital stay, these endoscopic reports were identified. This process of identifying different endoscopic reports for the same patient aimed to avoid bias and overestimate the number of patients underwent UGE.

To identify the frequency of diagnosis of NVUGIB secondary to peptic ulcer disease among patients underwent UGE, the monitored months in this study were divided into four periods: (1) July 2016 to December 2016; (2) year 2017; (3) year 2018; and, (4) year 2019.

The relative frequency of diagnosis of NVUGIB secondary to peptic ulcer disease in the four periods was identified using the following formula:

Number of patients with diagnosis of Frequency of NVUGIB secondary to peptic ulcer disease diagnosis (\%): in the period

Number of patients who underwent upper gastrointestinal endoscopy in the same period
In addition, the total relative frequency of NVUGIB diagnosis during the period of the study was calculated. To identify total frequency of diagnosis, the number of all the eligible patients with NVUGIB secondary to peptic ulcer disease diagnosis and the number of all the patients who underwent UGE during this study were considered (42 months).

To compare if there was a difference in the number of diagnoses of NVUGIB secondary to peptic ulcer disease in the respective four periods of the study, the chi-square for trend test was applied (BioEstat 5.3). The variables evaluated in this study were reported through descriptive statistics (absolute and relative frequency).

\section{RESULTS}

In the period from July 2016 to December 2019, 2,779 UGE were conducted. After identified different UGE performed for a same patient, 2,503 patients were evaluated.

One hundred and seventy eight patients with diagnosis of NVUGIB secondary to peptic ulcer disease were eligible, being: (1) 32 patients from July 2016 to December 2016; (2) 70 patients in 2017; (3) 39 patients in 2018; and, (4) 37 patients in 2019 ( $P$-value of qui-square test: 0.007). A mean of four diagnoses per month (standard deviation: \pm 3 ) was identified.

The index of agreement (kappa) among the researchers (Forgerini M, Urbano G, and Nadai TR) in the UGE analysis was 0.82 and the discrepancies were solved through clinical discussions and consensus. The flowchart of UGE analysis and primary and secondary exclusions were described in FIGURE 2.

The total frequency of diagnosis of NVUGIB secondary to peptic disease found was $7.1 \%$ considering the 42 months of UGE 
TABLE 1. Variables analyzed, data sources and measurement.

\begin{tabular}{|c|c|}
\hline Variable & Data source and measurement \\
\hline \multicolumn{2}{|c|}{ Non-variceal upper gastrointestinal bleeding and frequency of diagnoses } \\
\hline $\begin{array}{l}\text { Non-variceal upper } \\
\text { gastrointestinal bleeding } \\
\text { (NVUGIB) secondary to peptic } \\
\text { ulcer disease }\end{array}$ & $\begin{array}{l}\text { Diagnosis through upper gastrointestinal endoscopy (endoscopic findings of ulcer, cardiac or pyloric erosions, } \\
\text { acute gastric mucosal lesions, and erosive gastritis or duodenitis, with or without active or recent bleeding) } \\
\text { and clinical symptomatology (hematemesis, melena, hematochezia, intense sweating, dizziness, abdominal } \\
\text { pain, nausea or vomiting). }\end{array}$ \\
\hline $\begin{array}{l}\text { Total frequency of non-variceal } \\
\text { upper gastrointestinal bleeding } \\
\text { secondary to peptic ulcer disease }\end{array}$ & $\begin{array}{l}\text { Upper gastrointestinal endoscopies were evaluated for } 42 \text { months (July } 2016 \text { to December 2019). The } \\
\text { total frequency was calculated using the ratio of the number of patients diagnosed with non-variceal upper } \\
\text { gastrointestinal bleeding secondary to peptic disease during the study and divided by the total number of } \\
\text { upper gastrointestinal endoscopies performed. }\end{array}$ \\
\hline $\begin{array}{l}\text { Frequency of non-variceal } \\
\text { upper gastrointestinal bleeding } \\
\text { secondary to peptic ulcer disease }\end{array}$ & $\begin{array}{l}\text { The study four periods: (1) July } 2016 \text { to December 2016; (2) year 2017; (3) year 2018; and, (4) year } 2019 \text {. } \\
\text { The frequency in the four periods was calculated using the ratio of the number of patients diagnosed with } \\
\text { non-variceal upper gastrointestinal bleeding secondary to peptic disease in the respective period and divided } \\
\text { by the total number of upper gastrointestinal endoscopies performed in the same period. }\end{array}$ \\
\hline \multicolumn{2}{|c|}{ Variables recorded in the face-to-face interview } \\
\hline $\begin{array}{l}\text { Personal history of } \\
\text { gastrointestinal diseases and } \\
\text { family history of ulcer }\end{array}$ & $\begin{array}{l}\text { Personal history of dyspepsia (pain, burning in the stomach and/or feeling of slow digestion); bleeding } \\
\text { (melena and/or hematemesis); ulcer (gastric and/or duodenal); previous Helicobacter pylori infection and family } \\
\text { history of ulcer were recalled through self-report during the interviews. }\end{array}$ \\
\hline Drug therapy & $\begin{array}{l}\text { The drug therapy used in the two months prior to the onset of signs and symptoms of NVUGIB were recalled } \\
\text { through self-reports during the interviews and electronic medical records as a secondary source of information. }\end{array}$ \\
\hline Smoking habit & $\begin{array}{l}\text { The habit of smoking was recalled through self-reporting during the interviews and was stratified into: non- } \\
\text { smokers; ex-smokers and smokers. The amount of tobacco consumed by smokers was stratified as "moderate" } \\
\text { ( } 1 \text { to } 15 \text { cigarettes/day) and "heavy" (>15 cigarettes/day) })^{(17)} \text {. }\end{array}$ \\
\hline Alcohol consumption & $\begin{array}{l}\text { Alcohol consumption was recalled through self-report during the interviews and was stratified into: non- } \\
\text { consumption (abstainer) and "little" consumption ( } 0 \text { to } \leq 30 \text { grams of alcohol/day), "moderate" ( } 30 \text { to } \leq 90 \\
\text { grams of alcohol/day) and "heavy" ( }>90 \text { grams of alcohol/ day). In addition, alcohol consumption was stratified } \\
\text { into fermented beverages (beer, red and white wine) and distilled beverages (whiskey, cachaça and vodka) })^{(17)} \text {. }\end{array}$ \\
\hline
\end{tabular}

analysis. Therefore, it is estimated that for every 100 patients who underwent UGE, seven were diagnosed with NVUGIB secondary to peptic ulcer disease. Regarding the four periods established in this study, the frequency of diagnosis of $8.6 \%, 9.3 \%, 5.3 \%$, and $5.7 \%$ (FIGURE 3).

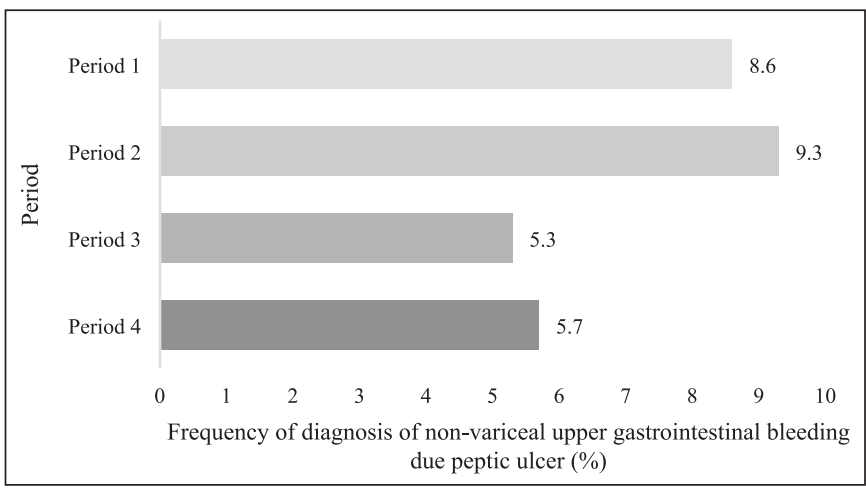

FIGURE 3. Frequency of diagnosis of non-variceal upper gastrointestinal bleeding secondary to peptic ulcer disease during the four periods* established by this study.

*Four periods of study: (1) July 2016 to December 2016; (2) year 2017; (3) year 2018; and, (4) year 2019.
The majority of patients diagnosed with NVUGIB secondary to peptic ulcer disease were men $(72.8 \%)$, self-declared white $(71.8 \%)$ and older than 60 years $(56.7 \%)$. The median age was 63 years (interquartile range: $50-74$ ), with a range of 18 to 93 years. $91.6 \%$ of the interviews were assigned with reliability scores between six to nine (TABLE 2). The main source of information during the interviews was the patient $(n=139)$.

The clinical symptoms most frequently reported by patients on hospital admission were melena $(62.8 \%)$, hematemesis $(45 \%)$, weight loss (43.3\%) and epigastric pain (31.1\%). 90\% of the patients, among other endoscopic findings, had peptic ulcers (duodenal or gastric), with $6 \%$ being of pre-pyloric origin. Considering that a patient may have more than one type of ulcer concurrently, 200 ulcerative findings were identified. Most ulcers were classified as Forrest IIa (62 ulcers) and III ( 86 ulcers). Ten percent of patients had only findings of pangastritis or erosive gastritis.

Thirty-nine patients underwent endoscopic hemostasis, being sclerotherapy $(n=38)$, and only endoscopic hemoclip $(n=1)$. The sclerotherapy was through injection of adrenalin and it was associated with endoscopic hemoclip $(n=5)$; ethamoline solution $(n=1)$ and electrocoagulation with argon $(n=1)$.

Fifteen patients had rebleeding episodes during the study period and four patients died during the hospitalization. 
TABLE 2. Demographic and clinical variables of the patients with diagnosis of non-variceal upper gastrointestinal bleeding secondary to peptic ulcer disease $(n=178)$ according to the four periods established in the study, Emergency Unity of Clinical Hospital of Ribeirão Preto Medical School of the University of São Paulo, July 2016 to December 2019.

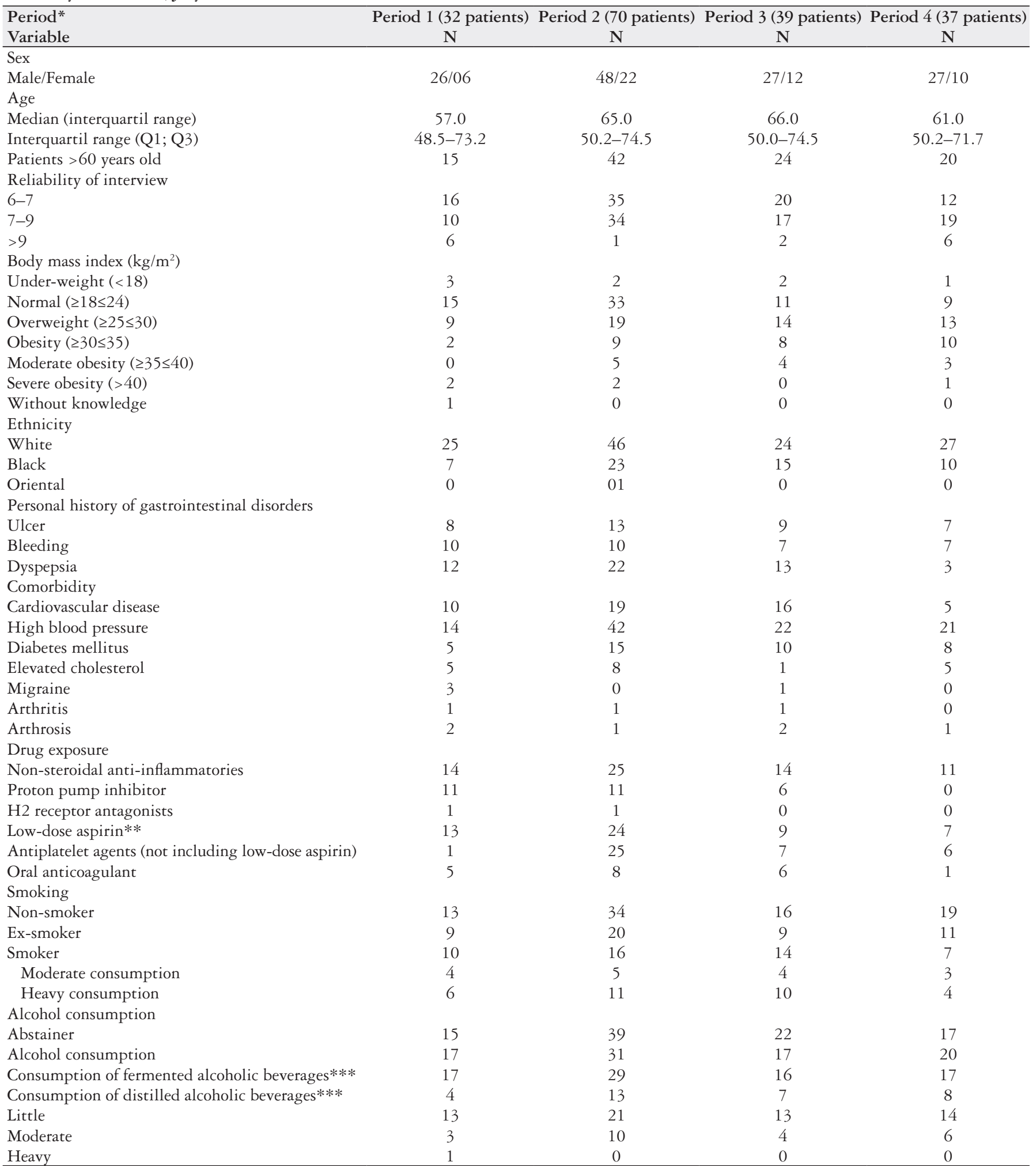

*The study established four periods: (1) July 2016 to December 2016; (2) Year 2017; (3) Year 2018; and, (4) Year 2019. **Low-dose aspirin was defined as aspirin at dose <300 milligrams per day. ***The same patient can consume fermented and distilled alcohol beverage concurrently. 
The most prevalent comorbidity was high blood pressure $(55.6 \%)$ followed by cardiovascular diseases $(28.1 \%)$, diabetes mellitus $(21.3 \%)$ and, dyslipidemia $(10.7 \%) .60 .1 \%$ of the patients had no family or personal history of gastrointestinal diseases, being: $21.7 \%$ patients had family history of ulcer and $28.1 \%$ had personal history of dyspepsia; $20.8 \%$ peptic ulcer and, 19.1\% hemorrhage. Only ten patients reported previous infection with Helicobacter pylori $(5.0 \%)$ (TABLE 2$)$.

Patients made chronic use of low-dose aspirin (LDA) (29.8\%), other antiplatelet agents $(21.9 \%)$, proton pump inhibitors $(15.7 \%)$ and, oral anticoagulants $(11.2 \%)$. Furthermore, $35.9 \%$ of patients use of non-steroidal anti-inflammatory drugs (NSAIDs) in the two months prior to the onset of signs and symptoms of NVUGIB secondary to peptic ulcer disease. However, 25.8\% patients made use of NSAIDs during the week before signs and symptoms of NVUGIB secondary to peptic ulcer disease (TABLE 2).

Regarding life habits, $85(47.7 \%)$ of the patients consumed alcoholic beverages in the two months prior to the onset of signs and symptoms of NVUGIB. Forty-seven $(26.4 \%)$ of the patients were smokers and forty-nine of the patients were ex-smokers (TABLE 2).

\section{DISCUSSION}

One hundred and seventy eight patients with diagnosis of NVUGIB secondary to peptic ulcer disease (mean of four diagnoses per month) and a total frequency of diagnoses of $7.1 \%$ were identified during this study (July 2016 to December 2019). Besides, it was observed statistical difference between frequency of diagnosis in the four periods of the study ( $P$-value: 0.007$)$.

Haro and Fey (2010) conducted a study at a Brazilian Emergency Hospital and identified 65 patients with NVUGIB diagnosis, with the majority of patients being elderly, male and white, corroborating with the demographic data identified in our study ${ }^{(21)}$. However, despite the relevant clinical discussion conducted by the authors, the study was conducted in 2008 and it is not clear the sample size, identification process of patients with NVUGIB diagnosis, as well as other important variables (i.e. coexisting comorbidities and drug exposure), in addition to inclusion of neoplastic, vascular and Mallory-Weiss tear etiology.

Considering other studies in the literature, rates of new diagnosis has high heterogeneity between countries ( 37 to 172/100,000 adults) ${ }^{(16)}$ and most of them estimated the incidence of upper gastrointestinal bleeding including both the varicose and non-varicose etiology ${ }^{(15,16,22)}$. This heterogeneity may be due to methodological and population aspects, since there are different study designs, sample size, criteria for upper gastrointestinal bleeding diagnosis, as well as variability between populations. From this perspective, the epidemiological profile of the patients, the drug prescription culture and, genetic variability are important aspects to be consider.

Most patients eligible in this study are men and elderly people, corroborating the findings of other studies ${ }^{(23-25)}$. Although we are not aware of any study justifying the higher incidence of NVUGIB in men, aging has been considered a significant risk factor for NVUGIB $^{(3,9,26)}$ and for non-gastrointestinal comorbidities that are also associated with increased risk and mortality from NVUGIB (i.e., cardiovascular disease) ${ }^{(1,27)}$. Furthermore, aging is related to the increased exposure to some drug classes, such as non-steroidal anti-inflammatory drugs (NSAIDs), LDA and, antiplatelet agents ${ }^{(9)}$. Exposure to these drugs and the risk of NVUGIB is well elucidated in the literature ${ }^{(1,10-12)}$, since NSAIDs and LDA is associated with gastric erosion, inhibition of platelet aggregation and consequently in the risk of ulcer and bleeding ${ }^{(28)}$.

Regarding population variability, ethnicity and ancestry are important factors that directly influence in the genetic variability among different populations ${ }^{(29,30)}$. In this context, some studies identified genetic susceptibility to the incidence of NVUGIB secondary to peptic ulcer disease ${ }^{(14,17,18)}$, as well as for rebleeding episodes ${ }^{(31)}$. Besides, use of LDA and NSAIDs in patients who have genetic variants in the $C Y P 2 C 9^{(17,32)}$ and $V K O C R I^{(24)}$, genes responsible for these drugs metabolism, might lead to an additive interaction and enhance the risks of NVUGIB secondary to peptic disease.

Ethnicity, in addition to influencing the presence of genetic variant, is also associated with the occurrence frequency of the variant $^{(29)}$. Most patients included in this study are white, which corroborates with the findings of Haro and Fey $(2010)^{(21)}$. However, some studies in the area included only white participants ${ }^{(17,25,32)}$, since some genetic variants has been more prevalent in self-declared white than black ones ${ }^{(33)}$. Therefore, a hypothesis to be tested is the presence of genetic variants and the risk of NVUGIB secondary to peptic ulcer disease considering all the variables identified in this study (i.e. ethnicity; comorbidities, drug exposure and, life habits), since there is no study in the Brazilian population ${ }^{(34)}$.

Another important factor to be considered is Helicobacter pylori infection. Patients with Helicobacter pylori infection have 6.8-fold higher risk of developing peptic ulcer disease ${ }^{(35)}$, the main etiology of NVUGIB ${ }^{(1)}$. However, in our study, only ten patients reported previous Helicobacter pylori infection and we consider this number underestimated. This hypothesis can be justified by the higher prevalence of Helicobacter pylori infection in developing countries $^{(9)}$, in addition to the unequal access to health systems and to diagnostic tests, since the cost may be considered relatively expensive $^{(36)}$.

Furthermore, the life habits of the population should also be taken into consideration, since the consumption of alcohol and tobacco, for instance, have also been associated with the risk of upper gastrointestinal bleeding ${ }^{(37,38)}$. In our study, most patients are abstainers and non-current smokers; however, such data may not represent the reality of other countries. In relation to tobacco consumption, there are several countries that have implemented smoking control policies, which may be related to the reduction in the number of smokers.

Lastly, our study shows a decrease in the proportion of diagnosis of NVUGIB secondary to peptic disease in the tertiary hospital of this study. This possible decrease can be justified by advances in medicine, such as the introduction of potent anti-acid secretion suppressant drugs and advances in diagnosis and therapeutic endoscopy ${ }^{(1,39)}$. From another perspective, despite the advances, the issue of access to health service remains, which can lead to late access and a worse prognosis, and even non-access ${ }^{(40)}$. Besides, another hypothesis is that the patients might go to other health services, consequently, reducing the number of UGE conducted in this Emergency unity hospital.

Hence, several risk factors might be associated with NVUGIB secondary to peptic disease risk, independently (i.e. aging, comorbidities) $)^{(9,27)}$ or synergistically (i.e. combination of NSAIDs and LDA use; drug exposure in addition to genetic variants) ${ }^{(15,17)}$. Therefore, these risk factors should be identified through a patient assessment to promote patient safety. In this line, Franco et al. (2015) proposed a clinical care pathway for the management of patients with NVUGIB hospitalized in tertiary hospital, which can 
contribute to standardization of medical practices, in addition to decrease of hospital length and costs ${ }^{(41)}$. Furthermore, the performance of the UGE in the first 24 hours of bleeding onset allowed a diagnostic accuracy ${ }^{(40)}$

Although the strength of this study is the diagnosis of NVUGIB secondary to peptic ulcer disease through UGE besides the clinical symptoms, the non-indication of potential patients with the diagnosis for UGE would lead to under-registration of diagnoses due to limitations of the health service or access to it. In addition, our study may have limitations to assess temporal trends since it was conducted for three and a half years and it was not possible to calculate population-based incidence, since only an Emergency hospital was assessed.

Indeed, our study has several strengths: a) this is the first Brazilian study to assess the frequency of diagnosis of NVUGIB secondary to peptic disease; b) the study lead time can reduce the risk of bias due to seasonality in the frequency of NVUGIB diagnosis; c) the process of UGE monitoring was conducted by three researchers, independently, reducing the selection bias; and, d) the interviews conducted face-to-face allowed to reduce the data collection bias in databases. In addition, it is relevant to highlight that the inclusion and exclusion criteria of this study were carefully designed in order to identify patients diagnosed with NVUGIB secondary to peptic ulcer disease as a possible adverse drug reaction, excluding other possible confounding etiologies.

\section{CONCLUSION}

The total frequency of NVUGIB secondary to peptic disease was about seven patients for every hundred patients addmited in a tertiary hospital and underwent UGE. The majority of patients are men; older people; self-declared white; diagnosed with high blood pressure, cardiovascular diseases, and diabetes mellitus; with no family or personal history of gastrointestinal diseases; abstainers and, non-current smokers. Furthermore, our data may suggest a possible decrease in the number of diagnosis of NVUGIB secondary to peptic ulcer disease in the tertiary hospital of this study.

\section{ACKNOWLEDGMENTS}

The authors thank the Professor Dr Adolfo Figueiras Guzmán (Universidad de Santiago de Compostela) and Dr Maria Teresa Herdeiro (Universidade de Aveiro) for their contributions to this study.

\section{Authors' contribution}

Forgerini M participated in methodology, formal analysis, investigation, data curation, writing-original draft, and writing-review and editing. Urbano $\mathrm{G}$ and Nadai TR participated in methodology, formal analysis, investigation, data curation and writing-review and editing. Zapata-Cachafeiro M, participated in conceptualization, methodology, formal analysis, data curation and writing-review and editing. Kemp R participated in formal analysis, data curation and writing-review and editing. Mastroianni PC participated in conceptualization, methodology, formal analysis, data curation, writing-review and editing, project administration and, funding acquisition.

\section{Orcid}

Marcela Forgerini: 0000-0002-2905-8519.

Gustavo Urbano: 0000-0002-6011-4697.

Tales Rubens de Nadai: 0000-0003-0638-2399.

Maruxa Zapata-Cachafeiro: 0000-0002-0648-7716.

Rafael Kemp: 0000-0001-8008-2322.

Patrícia de Carvalho Mastroianni: 0000-0001-8467-7278.

Forgerini M, Urbano G, Nadai TR, Zapata-Cachafeiro M, Kemp R, Mastroianni PC. Perfil epidemiológico de pacientes com hemorragia gastrointestinal alta não varicosa decorrente de doença péptica em um hospital brasileiro terciário de referência. Arq Gastroenterol. 2021;58(2):202-9.

RESUMO - Contexto - A hemorragia digestiva alta não varicosa (HDANV) secundária à úlcera péptica é uma emergência médica digestiva e pode ser uma reação adversa a medicamento severa. Objetivo - Estimar a frequência de HDANV secundária à doença péptica. Métodos - Estudo prospectivo e epidemiológico realizado em um hospital brasileiro terciário de referência, no período de julho de 2016 a dezembro de 2019. Os laudos de endoscopia gastrointestinal alta foram avaliados diariamente. O diagnóstico de HDANV secundária para úlcera péptica foi definido por achados endoscópicos de úlcera péptica e lesões gástricas erosivas e sintomas clínicos. A frequência de diagnóstico de HDANV secundária à úlcera péptica foi estimada por meio da razão entre o número de pacientes diagnosticados e o número de pacientes submetidos à endoscopia gastrointestinal alta no mesmo período. Resultados - Um total de 2.779 laudos endoscópicos (2.503 pacientes) foram avaliados e 178 pacientes foram elegíveis. A frequência total de diagnóstico de HDANV secundária à úlcera péptica foi de 7,1\%. A frequência anual de diagnósticos entre 2017 e 2019 variou de 9,3\% a 5,7\%. A maioria dos pacientes era do sexo masculino ( $72,8 \%)$; auto-declarado branco $(71,8 \%)$; idoso $(56,7 \%)$; e não possuía histórico familiar ou pessoal de doenças gastrointestinais $(60,1 \%) .90 \%$ dos pacientes apresentaram úlcera péptica e melena (62,8\%). Os pacientes faziam uso crônico de ácido acetilsalicílico como antiagregante plaquetário (29,3\%), outros antiplaquetários $(21,9 \%)$ e anticoagulantes orais $(11,2 \%)$; e fizeram uso e uso de anti-inflamatórios não esteroidais na semana anterior ao início dos sintomas clínicos de HDANV $(25,8 \%)$. Conclusão - Cerca de sete em cada 100 pacientes admitidos em um hospital terciário e submetidos à endoscopia gastrointestinal alta foram diagnosticados com HDANV secundária à úlcera péptica.

Palavras-chave - Endoscopia gastrointestinal; epidemiologia; hemorragia gastrointestinal; hospitalização; segurança do paciente; úlcera péptica. 


\section{REFERENCES}

1. Lanas A, Dumonceau JM, Hunt RH, Fujishiro M, Scheiman JM, Gralnek IM, et al. Non-variceal upper gastrointestinal bleeding. Nat Rev Dis Prim. 2018;4:18020.

2. Rahman SIU, Saeian K. Nonvariceal Upper Gastrointestinal Bleeding. Crit Care Clin. 2016;32:223-39. DOI: 10.1016/j.ccc.2015.12.002.

3. Laine L. Upper Gastrointestinal Bleeding Due to a Peptic Ulcer. Solomon CG, editor. N Engl J Med. 2016;374:2367-76.

4. Quan S. Upper-gastrointestinal bleeding secondary to peptic ulcer disease: Incidence and outcomes. World J Gastroenterol. 2014;20:17568.

5. Jairath V, Martel M, Logan RFA, Barkun AN. Why Do Mortality Rates for Nonvariceal Upper Gastrointestinal Bleeding Differ around the World? A Systematic Review of Cohort Studies. Can J Gastroenterol. 2012;26:537-43.

6. Hearnshaw SA, Logan RFA, Lowe D, Travis SPL, Murphy MF, Palmer KR. Acute upper gastrointestinal bleeding in the UK: Patient characteristics, diagnoses and outcomes in the 2007 UK audit. Gut. 2011;60:1327-35.

7. Feinman M, Haut ER. Upper Gastrointestinal Bleeding. Surg Clin North Am. 2014;94:43-53.

8. Pirmohamed M, James S, Meakin S, Green C, Scott AK, Walley TJ, et al. Adverse drug reactions as cause of admission to hospital: prospective analysis of 18820 patients. BMJ. 2004;329:15-9.

9. Sostres C, Lanas A. Epidemiology and Demographics of Upper Gastrointestina Bleeding: Prevalence, Incidence, and Mortality. Gastrointest Endosc Clin N Am. 2011;21:567-81.

10. Lanas Á, Carrera-Lasfuentes P, Arguedas Y, García S, Bujanda L, Calvet X, et al. Risk of Upper and Lower Gastrointestinal Bleeding in Patients Taking Nonsteroidal Anti-inflammatory Drugs, Antiplatelet Agents, or Anticoagulants. Clin Gastroenterol Hepatol. 2015;13:906-12.

11. Lanas A, García-Rodríguez LA, Arroyo MT, Gomollón F, Feu F, González-Pérez A, et al. Risk of upper gastrointestinal ulcer bleeding associated with selective cyclo-oxygenase-2 inhibitors, traditional non-aspirin non-steroidal anti-inflammatory drugs, aspirin and combinations. Gut. 2006;55:1731-8.

12. Lanas A, Bajador E, Serrano P, Fuentes J, Carreño S, Guardia J, et al. Nitrovasodilators, Low-Dose Aspirin, Other Nonsteroidal Antiinflammatory Drugs, and the Risk of Upper Gastrointestinal Bleeding. N Engl J Med. 2000;343:834-9.

13. Shiotani A, Murao T, Fujita Y, Fujimura Y, Sakakibara T, Nishio K, et al. Single nucleotide polymorphism markers for low-dose aspirin-associated peptic ulcer and ulcer bleeding. J Gastroenterol Hepatol. 2014;29:47-52.

14. Wu Y, Hu Y, You P, Chi Y-J, Zhou J-H, Zhang Y-Y, et al. Study of Clinical and Genetic Risk Factors for Aspirin-induced Gastric Mucosal Injury. Chin Med J (Engl). 2016;129:174-80.

15. Hreinsson JP, Kalaitzakis E, Gudmundsson S, Björnsson ES. Upper gastrointestinal bleeding: Incidence, etiology and outcomes in a population-based setting. Scand J Gastroenterol. 2013;48:439-47.

16. van Leerdam ME. Epidemiology of acute upper gastrointestinal bleeding. Best Pract Res Clin Gastroenterol. 2008;22209-24.

17. Figueiras A, Estany-Gestal A, Aguirre C, Ruiz B, Vidal X, Carvajal A, et al. CYP2C9 variants as a risk modifier of NSAID-related gastrointestinal bleeding: A case-control study. Pharmacogenet Genomics. 2016;26:66-73.

18. Mallah N, Zapata-Cachafeiro M, Aguirre C, Ibarra-García E, Palacios-Zabalza I, Macías-García F, et al. Influence of Polymorphisms Involved in Platelet Activation and Inflammatory Response on Aspirin-Related Upper Gastrointestinal Bleeding: A Case-Control Study. Front Pharmacol. 20209;11:860.

19. Von Elm E, Altman DG, Egger M, Pocock SJ, Gøtzsche PC, Vandenbroucke JP. The Strengthening the Reporting of Observational Studies in Epidemiology (STROBE) statement: guidelines for reporting observational studies. J Clin Epidemiol. 2008;61:344-9.

20. Forrest J. AH, Finlayson ND. DC, Shearman DJ. JC. Endoscopy in gastrointestinal bleeding. Lancet. 1974;304:394-7.

21. Haro CP, Fey A. Analysis of the epidemiological, treatment and evolution of patients with upper gastrointestinal bleeding admitted to the emergency Hospital Regional Alto Vale. Arq Catarinenses Med. 2010;39:51-6.

22. Danis N, Tekin F, Akarca US, Unal NG, Erdogan EI, Akat K, et al. Changing patterns of upper gastrointestinal bleeding over 23 years in Turkey. Turkish J Gastroenterol. 2019;30:877-82.
23. Wang T. Association between TNF- $\alpha$ polymorphisms and the risk of upper gastrointestinal bleeding induced by aspirin in patients with coronary heart disease. Ann Hum Genet. 2019;83:124-33.

24. Groza I, Matei D, Tanțău M, Trifa AP, Crișan S, Vesa SC, et al. VKORC1-1639 $\mathrm{G}>$ A polymorphism and the risk of non-variceal upper gastrointestinal bleeding. J Gastrointest Liver Dis. 2017;26:13-8.

25. Piazuelo E, Fuentes J, Garcfa-González MA, Jiménez P, Lanas A. A case-control study of the association between polymorphisms of the endothelial nitric oxide synthase and glycoprotein IIIa genes and upper gastrointestinal bleeding in users of low-dose aspirin. Clin Ther. 2008;30:121-30.

26. Marques SB, Mattar R, Artifon ELA, Sakai P, Carrilho FJ. High prevalence of duodenal ulcer in a tertiary care hospital in the city of São Paulo, SP, Brazil. Arq Gastroenterol. 2011;48:171-4.

27. Crooks CJ, West J, Card TR. Comorbidities affect risk of nonvariceal upper gastrointestinal bleeding. Gastroenterology. 2013;1441384-93.

28. de Carli DM, Pires RC, Rohde SL, Kavalco CM, Fagundes RB. Diferentes frequências da úlcera péptica relacionadas com H. pylori ou AINES. Arq Gastroenterol. 2015;52:46-9.

29. Ramos E, Doumatey A, Elkahloun AG, Shriner D, Huang H, Chen G, et al. Pharmacogenomics, ancestry and clinical decision making for global populations. Pharmacogenomics J. 2014;14:217-22

30. Li J, Zhang L, Zhou H, Stoneking M, Tang K. Global patterns of genetic diversity and signals of natural selection for human ADME genes. Hum Mol Genet. 2011;20:528-40.

31. Kim H-S, Hwang K-Y, Chung I-K, Park S-H, Lee M-H, Kim S-J, et al. Tissue Plasminogen Activator and Plasminogen Activator Inhibitor Type 1 Gene Polymorphism in Patients with Gastric Ulcer Complicated with Bleeding. J Korean Med Sci. 2003;18:58

32. Pilotto A, Seripa D, Franceschi M, Scarcelli C, Colaizzo D, Grandone E, et al. Genetic Susceptibility to Nonsteroidal Anti-Inflammatory Drug-Related Gastroduodenal Bleeding: Role of Cytochrome P450 2C9 Polymorphisms. Gastroenterology. 2007;133:465-71.

33. Rodrigues-Soares F, Kehdy FSG, Sampaio-Coelho J, Andrade PXC, Céspedes-Garro C, Zolini C, et al. Genetic structure of pharmacogenetic biomarkers in Brazil inferred from a systematic review and population-based cohorts: a RIBEF/EPIGEN-Brazil initiative. Pharmacogenomics J. 2018;18:749-59.

34. Forgerini M, Lucchetta RC, Urbano G, de Nadai TR, de Carvalho Mastroianni P. Genetic polymorphisms associated with upper gastrointestinal bleeding: a systematic review. Pharmacogenomics J. 2021;21:20-36. DOI: 10.1038/s41397020-00185-6.

35. Li Z, Zou D, Ma X, Chen J, Shi X, Gong Y, et al. Epidemiology of Peptic Ulcer Disease: Endoscopic Results of the Systematic Investigation of Gastrointestinal Disease in China. Am J Gastroenterol. 2010;105:2570-7.

36. Burkitt MD, Duckworth CA, Williams JM, Pritchard DM. Helicobacter pylori -induced gastric pathology: insights from in vivo and ex vivo models. Dis Model Mech. 2017;10:89-104.

37. Andersen IB, Jørgensen T, Bonnevie O, Grønbæk M, Sørensen IA. Smoking and alcohol intake as risk factors for bleeding and perforated peptic ulcers: A population-based cohort study. Epidemiology. 2000;11:434-9.

38. Gallerani M, Simonato M, Manfredini R, Volpato S, Vigna G., Fellin R. Risk of hospitalization for upper gastrointestinal tract bleeding. J Clin Epidemiol. 2004; $57: 103-10$

39. Targownik LE, Nabalamba A. Trends in Management and Outcomes of Acute Nonvariceal Upper Gastrointestinal Bleeding: 1993-2003. Clin Gastroenterol Hepatol. 2006;4:1459-66.

40. Zaltman C, De Souza HSP, Castro MEC, Sobral M de FS, Dias PCP, Lemos V. Upper gastrointestinal bleeding in a Brazilian hospital: A retrospective study of endoscopic records. Arq Gastroenterol. 2002;39:74-80.

41. Franco MC, Nakao FS, Rodrigues R, Maluf-Filho F, de Paulo GA, Libera E Della. Proposal of a clinical care pathway for the management of acute upper gastrointestinal bleeding. Arq Gastroenterol. 2015;52:283-92. DOI: 10.1590/ S0004-28032015000400007. 